\title{
Introduction: the quantity theory of money - why another restatement is needed, and why it matters to the debates on the Great Recession
}

\section{Tim Congdon}

Were bankers the only culprits for the Great Recession of late 2008 and 2009? Were governments and politicians responsible to some extent? And did central banks and regulators make mistakes? Was the Great Recession, which had many echoes back to the Great Depression of 1929-33, attributable to the faults of free-market capitalism or blunders in public policy? Indeed, do economies with a privately owned, profit-motivated financial system have a systemic weakness? Do they suffer - intrinsically and inevitably - from extreme and unnecessary cyclical instability in demand, output and employment? Or were both the Great Depression and the Great Recession due to faulty public policies and misguided action by the state?

These questions are some of the most contentious in contemporary economic debate. The purpose of the collection of essays in the current volume is to throw light on them both by identifying and analysing possible causes of the relatively recent Great Recession, and by comparing the intellectual response to the Great Recession with that to the Great Depression roughly 80 years earlier. The exercise is inherently problematic. A range of causal influences might be probed, at different levels of remoteness from the key events. For example, a valid and interesting approach would be to survey the macroeconomic ideas held by the principal decision-takers, and the development of their beliefs from the start of their careers. Such books as Ben Bernanke's The Courage to Act, Mervyn King's The End of Alchemy and Hank Paulson's On the Brink do indeed give insights into the aetiology of the Great Recession. ${ }^{1}$ But they have not settled the issue of why so much, so quickly, went wrong in the main Western economies in late 2008.

Inescapably, any approach has to be selective to some degree. The 
focus here is on what is termed "the monetary interpretation of the Great Recession". In this interpretation movements in demand (and hence in output and employment) are seen as reflecting prior or coincident movements in the quantity of money. The quantity of money is understood to play a major causal role in cyclical instability. The monetary interpretation of the Great Recession pivots on the proposition that the collapses in economic activity seen in the worst quarters of 2008 and 2009 were due to falls in - or at any rate sharp declines in the growth rate of - the quantity of money. Moreover, as the Great Recession was international in scope, this claim needs to be credible in several countries. When the evidence is assembled, all of the badly affected countries ought to have reported marked weakness in money growth at some stage in the Great Recession.

Discussion of the Great Recession needs to be set in the context of previous thinking about macroeconomic instability and, in particular, thinking about the Great Depression. For most of the 1930s and 1940s the Great Depression was regarded as a failure of free-market capitalism, and so as justifying some sort of government intervention to boost output and to create jobs. The performance of the American economy, where real national output fell by a quarter from autumn 1929 to the start of 1933, was contrasted unfavourably with the apparent triumph of Stalin's first five-year plan (1928-32) in the communist Soviet Union. According to no doubt exaggerated official Russian statistics, the plan more than tripled the output of heavy industry.

Many thoughtful and well-intentioned people, around the world, concluded that in future economic progress would be promoted by centralized planning. Moreover, a plausible view was that centralized planning would be easier to implement in a society with extensive public ownership of property. The Soviet Union's victory in the Second World War further boosted the prestige of socialist doctrine, and heartened European and American critics of the free-market system. Even in the 1950s and early 1960s belief in the efficiency and success of the Soviet economy was widely held in Western countries, notably among many top academics and civil servants. ${ }^{2}$ So widespread was the admiration for the communist economic model that a 1961 book questioning Soviet propaganda was given the sarcastic title Are the Russians Ten Feet Tall? ${ }^{3}$ While Western economies achieved far better macroeconomic stability in the first two decades after the Second World War than in the 1930s, the improvement was not attributed to their underlying characteristics and certainly not to 
capitalist patterns of property ownership. Instead the accolade was usually given to the so-called "Keynesian revolution". This revolution, inspired by John Maynard Keynes's 1936 classic work The General Theory of Money, Interest and Employment, was often understood - or even defined - as the expansion of the state's control over the economy.

An important corrective came in 1963 with the publication of $A$ Monetary History of the United States 1867-1960 by Milton Friedman and Anna Schwartz. Its authors knew that the Great Depression was viewed as a black mark against capitalism, and particularly against the Wall Street financial institutions that were alleged to have ramped up share prices to unsustainable levels in 1929. The heart of the Friedman and Schwartz counter-argument relied on the quantity theory of money, which asserted that a long-run relationship held between changes in the quantity of money and nominal national income. To test the hypothesis they put together monetary data for the USA over many past decades. They identified a big drop in the quantity of money, of almost 40 per cent between October 1929 and April 1933, as a distinctive feature of the period. ${ }^{4}$ They further proposed that monetary policy was the main causal driver behind the crash in the money supply, and hence the slump in demand and output. Controversially, they denounced the American central bank, the Federal Reserve, for the plunge in the quantity of money.

The larger message was that free enterprise did not produce the Great Depression. On the contrary, blame should fall on the incompetence of a state-sponsored institution. To quote, "A governmentally established agency - the Federal Reserve System - had been assigned responsibility for monetary policy. In 1930 and 1931 it exercised this responsibility so ineptly as to convert what would otherwise have been a moderate contraction into a major catastrophe." 5 The analysis carried a powerful implication. As long as those in charge of monetary policy were able to maintain stable growth of money from year to year, a capitalist economy would grow smoothly. Cyclical wobbles might persist, but they would be minor and manageable. According to Friedman and Schwartz, free-market capitalism was a benign and efficient method of organizing an economy, and it did not suffer because of its inherent characteristics - from serious instability.

Their thesis has been much challenged. In his 1973 book on The World in Depression 1929-39, Charles Kindleberger, often regarded as the doyen of American mid-twentieth-century economic historians, set the American slump in an international context and preferred a multi-causal explanation of events. There can be little doubt that a majority of academic economists distrusted the mono-causality of the Friedman and Schwartz view. Robert Solow, a colleague of Kindleberger's at the Massachusetts Institute of Technology, mocked that, "Everything reminds Milton of the 
money supply. Well, everything reminds me of sex, but I keep it out of my papers". ${ }^{6}$ Even so the significance of the argument in A Monetary History of the United States was quickly and widely recognized.

In the 1940s and 1950s the USA's political debate seemed to be moving ever further away from the individualism and aversion to state action that had characterized its first 150 years as an independent nation. But from the 1960s a conservative reaction gathered momentum. According to George Nash in his 1976 The Conservative Intellectual Movement in America since 1945, the thesis of A Monetary History represented a "liberating revisionism" that "rapidly became part of the conservative scholarly arsenal". ${ }^{7}$ A Monetary History was highly empirical, but Friedman expanded the discussion with both theoretical contributions to professional journals and readable newspaper articles. Such was his effectiveness in espousing his views that he is often said to have pioneered "the monetarist counter-revolution" against "the Keynesian revolution". ${ }^{8}$ As David Laidler remarks at the end of Chapter 10 below, "Most economists continue to accord deep respect to the Monetary History." If today its main issues are very much back on the agenda, that testifies to "the enduring importance of this great book". ${ }^{9}$

For over 25 years Friedman was the leading figure in the University of Chicago's economic faculty. From some date in the 1940s the term "Chicago School" began to circulate. It referred to both the enthusiasm for the free market expressed by Friedman and his colleagues, and to the importance that Chicago economists placed on good monetary management to the success of capitalist economies. Friedman's influence extended far beyond Chicago. As a student at the MIT in the 1970s, Bernanke read A Monetary History and found it "fascinating". In his words, "After reading Friedman and Schwartz, I knew what I wanted to do. Throughout my academic career, I would focus on macroeconomic and monetary issues." 10

The Friedman and Schwartz position may not be universally accepted, but even its antagonists concede that it has analytical force and integrity. What, then, is to be said about the Great Recession? If an almost 40 per cent drop in the quantity of money can be condemned as the villain of the piece in the Great Depression, what is to be said about the behaviour of the quantity of money in the Great Recession? One problem for Friedman and Schwartz was that the indispensable money numbers required rearrangement as well as interpretation when they started their research. ${ }^{11}$ Since official economic statistics were rudimentary in the late nineteenth and early twentieth centuries, they had to compile monetary data using a range of disparate sources. Nowadays all central banks publish comprehensive money supply numbers after only a short lag. Indeed, the USA has weekly 


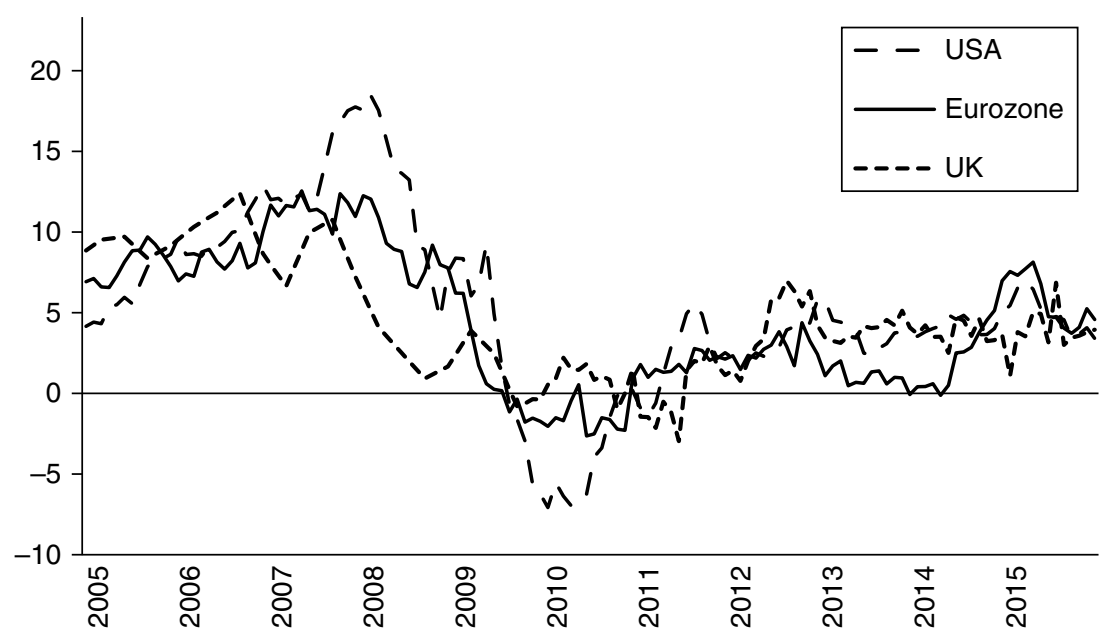

Figure I.1 Growth rates of money in the USA, the Eurozone and the UK, 2005-15 (\% annualized growth rate of the quantity of money in the last six months)

figures for the money supply which are available in a matter of days from the date to which they relate.

What happened to the quantity of money, in the USA and elsewhere, in the critical period from 2007 to 2010? Did the change in the quantity of money slow markedly in these years? If so, what does that imply for causality? Can it be proposed, along the lines of the Friedman and Schwartz thesis about the Great Depression, that the Great Recession was the result of a collapse in money growth? Was the Great Recession then due to crass decisions by officialdom, and not to the follies and inadequacies of the capitalist financial system? Figure I.1 shows the behaviour, in terms of the annual rates of change over six-month periods, of (one measure of) the quantity of money in three major advanced monetary jurisdictions, the USA, the Eurozone and the United Kingdom, in the decade from 2005. ${ }^{12}$ (The identity of this measure will soon be disclosed.) Along with Japan, the nations in this group have accounted for over 60 per cent of world output for most of the last 50 years and their impact on global demand growth remains profound. It is immediately clear that a decline in rate of change in the quantity of money must have had a role in the Great Recession, just as it did in the Great Depression. Between late 2008 and 2010 - the period in which the Great Recession hit - money growth fell sharply in all three of the jurisdictions. The fall was particularly severe in the USA, where the change was from almost plus 20 per cent at the peak to minus 7 per cent at 
the trough. Although more research and analysis are needed before strong statements about causality can be ventured, the graph does establish the case for conducting that research and analysis, and so provides the rationale for the current volume.

Because Friedman was crucial to the monetarist counter-revolution, it makes sense to review his ideas and beliefs in this area of economics. $\mathrm{He}$ never claimed that his thinking was particularly original, acknowledging intellectual indebtedness to forerunners at the University of Chicago and Irving Fisher (1867-1947), the first champion of the quantity theory of money. In fact, when asked to define his position Friedman preferred the phrase "the quantity theory of money" to the new-fangled word "monetarism". Unfortunately, both the quantity theory of money and monetarism are elusive schools of thought. Supposedly authoritative statements are beset by looseness of definition and conceptual inconsistency. ${ }^{13}$ This lack of clarity was part of the motivation for one of Friedman's most celebrated papers, 'The quantity theory of money: a restatement', which appeared in 1956 and is generally regarded as the theoretical launching-pad for the monetary counter-revolution. It highlighted how the demand to hold money balances needed to be set within a rigorous microeconomic framework, as one asset in portfolios with many non-monetary assets. In Friedman's words, "the theory of the demand for money is a special topic in the theory of capital". ${ }^{14}$ The technical sophistication of the 1956 paper buttressed the quantity theory's core empirical tenet, that the quantity of money and national income move at similar rates over the long run.

But the critics were not satisfied. Paul Samuelson, a leading Keynesian economist and an articulate opponent of Friedman's analyses, judged that A Monetary History had too much history and narrative, and was light on theory. In a 1969 comment on US stabilization policies, he decried "garden-variety monetarism" as "a black-box theory", with "mechanistic regularities" that were unreliable because they could not be "spelled out by a plausible economic theory".${ }^{15} \mathrm{He}$ sneered at the monetarists, making the charge that they had not elucidated in detail the channels by which money balances affected wealth and expenditure. The black-box allegation has stuck, with the phrase appearing in the title of a widely quoted 1995 paper, 'Inside the black box: the credit channel of monetary policy transmission', by Bernanke and Mark Gertler. ${ }^{16}$ The 1995 paper helped to establish Bernanke's academic reputation and so to put him on the path to 
becoming chairman of the Federal Reserve in February 2006, a mere two years before the start of the Great Recession.

Friedman and other monetarists rejected the black-box allegation. Even a casual glance at his publications shows that Friedman repeatedly applied price-theoretic tools to monetary analysis. He shared Keynes's belief, stated in The General Theory, that national income and wealth were determined only when the demand to hold money balances was equal to the quantity of money created by the banking system. ${ }^{17}$ In the same year that their highly readable Monetary History was published, Friedman and Schwartz placed a more technical paper on 'Money and business cycles' in The Review of Economics and Statistics. ${ }^{18}$ Here they went to considerable lengths to specify and explain the process of connection between money and macroeconomic outcomes, although they did not use Samuelson's word "channel". Their "tentative sketch of the mechanism transmitting monetary changes" detailed numerous links from a change in the rate of monetary growth to interest rates and asset prices, and thence to the demand for capital goods, including houses and consumer durables, and on to macroeconomic activity as a whole, including ultimately to wages and prices. ${ }^{19}$

However, in two important respects Friedman's critics drew blood, and the wounds were deep and lasting, and still have not properly healed. First, as several definitions of the "quantity of money" have been proposed, the concept is bedevilled by ambiguity. Money is usually understood to consist of assets that are valid for use in transactions and constant in nominal-value terms when they are so used. ${ }^{20}$ One definition (of so-called "broad money", denoted by M2, M3 or M4, depending on the nation under consideration) encompasses every asset that might conceivably be money. Typically broad money is equal to notes and coin in circulation with the public, and all of banks' deposit liabilities to genuine non-bank private sector agents. ${ }^{21}$ By contrast, "narrow money" (M1) includes notes and coin in circulation with the public and only bank deposits that are available for spending without notice. (Such deposits are called "demand deposits" or "sight deposits" in American parlance and "current accounts" in British.)

A tricky question arises, "to which concept of money - narrow or broad - do the key monetarist propositions relate?". The question is much deeper and more troublesome than it seems. In 2008, as the Great Recession was unfolding, M1 in the USA was about $\$ 1400$ billion, which was under 10 per cent of nominal gross domestic product, whereas M3 was heading towards $\$ 14000$ billion and was roughly the same size as GDP. ${ }^{22}$ There are monetarist economists who ground their macroeconomic analyses in M1, and downplay or ignore broad money. These are exemplified 
by Allan Meltzer in his history of the Federal Reserve, which defined the stock of money as "currency and demand deposits". ${ }^{23}$ But the channels of interaction between money and the economy must be radically different for M1 and M3. It is difficult to believe that changes in M1 could impact on portfolio decisions and expenditure commitments in the same way, or to the same extent, as changes in M3.

Friedman made numerous comments on the "which aggregate?" debate in his career, but they varied over the decades. The argument in A Monetary History about the causes of the Great Recession relied on the behaviour of broad money. This feature of the book was noted by, for example, Robert Lucas, the leader of the so-called New Classical School and a Nobel laureate who developed elements of monetarist thinking in his own work. ${ }^{24}$ On the whole Friedman's preference was indeed for broad money and, more specifically, for the M2 aggregate where the Federal Reserve's own series starts in $1959 .{ }^{25}$ But in the early 1980s he shifted towards the narrow money measure, M1, the growth of which was targeted for a few years by the Federal Reserve in the big anti-inflation drive during Paul Volcker's chairmanship. The shift to M1 proved to be a serious error. It caused Friedman to predict an upturn in inflation in the mid-1980s, which simply did not happen. The forecasting mistake undermined his credibility in both academic and policy-making circles. ${ }^{26}$ Later he renewed his allegiance to broad money, particularly to M2.

Friedman was far from being alone in failing to stick loyally to one money measure. The chopping and changing alienated many observers who might otherwise have been interested in quantity-theory ideas. At about the same time as Friedman's flirtation with M1, in the UK the Labour politician, Peter Shore, scorned the money supply as "a wayward mistress" for policy-makers. The "which aggregate?" debate continues to reverberate, as the Great Recession was accompanied by sharp divergences in the growth rates of different money aggregates in the leading nations. But - as will emerge in this volume - the experience of the Great Recession has gone far to confirm the correctness of the emphasis on broad money in A Monetary History. (To end the suspense, the money measure in the graph in Figure I.1 was broadly defined.)

\section{III}

The squabbles about the aggregates were bad for monetarism's public image. But the second conceptual wound inflicted by the anti-monetarists was perhaps even more fundamental. Most macroeconomists - including undoubted Keynesians such as Paul Samuelson - accepted that the equality 
of the demand to hold money with the actual quantity of money in the economy is a condition of macroeconomic equilibrium. In other words, they agreed with Friedman that large changes in national income are likely to be associated with large changes in the quantity of money. ${ }^{27}$ However, that raised the question of how the quantity of money is determined. Since most of broad money consists of bank deposits, their creation must in some sense be the work of the banking system. But how exactly does money come into being? By what process or processes do banks introduce new money into the economy?

In one of his theoretical papers Friedman ducked the issue by appealing to "helicopter money", conjuring up a vision of bank notes falling from the sky. ${ }^{28}$ This was obviously an imaginative conceit intended only to aid exposition. Even so, it caused widespread amusement and even derision. ${ }^{29}$ Friedman may have wanted to recall the era when gold or silver were the principal monetary assets, and the quantity of money increased adventitiously - as if out of the sky - when new mines were discovered. Nowadays money has ceased to be a commodity like a precious metal. Instead all money is a liability of banks, whether it takes the form of legaltender notes issued by the central bank or of deposits issued by commercial banks. In one sense the creation of new money in this sort of world, the world of so-called "fiat money", is straightforward. Because the central bank's notes are legal tender and must be taken in payment, they can be increased by the simultaneous addition of identical sums to both sides of its balance sheet. Shockingly (or so it seems), new money comes out of "thin air". As Galbraith remarked in his 1975 Money: Whence it Came, Where it Went, "The process by which money is created is so simple that the mind is repelled." 30

At first glance commercial banks are in a similar position. People believe that payments can be made from bank deposits, as long experience has established that this is the case. It seems to follow that deposits can be increased by the simultaneous addition of identical sums to both sides of a bank's balance sheet. The expansion of its balance sheet occurs if a bank sees a profitable opportunity to buy a security (when it credits a sum to the account of the person who sells the security and the security becomes part of its assets) or to make a new loan (when it credits a sum to the borrower's deposit, which is its liability, and registers the same sum on the assets side of the balance sheet as a loan). It is certainly the case that in modern circumstances much money creation does take place in this way, so that deposits have been described as "fountain-pen money", "cheque-book money" or "keyboard money" to reflect the ever-evolving technology of writing. ${ }^{31}$

But there is a catch. Commercial banks do not have the power to issue legal-tender cash. Since they must at all times be able to convert customers' 
deposits back into central bank notes, they must keep a cash reserve (partly in their vaults and tills, and partly in a deposit at the central bank) to meet deposit withdrawals. If an individual bank expands its balance sheet too quickly relative to other banks, it may find its deposits have become so large that cash withdrawals exceed cash inflows. Potentially it could run out of cash. The expansion of deposits by commercial banks is therefore constrained by the imperative to maintain a positive cash reserve. Indeed, over multi-decadal periods in many nations commercial banks have kept a relatively stable ratio of cash to their deposit liabilities.

The discussion in the last few paragraphs has suggested two approaches to conceptualizing the creation of money in a fiat-money economy. The creation of money can be seen, first, as the result of the extension of credit by the banking system, where it is consolidated and embraces both the central bank and the commercial banks. The "credit counterparts" on the assets side of the consolidated banking system's balance sheet must equal the liabilities on the other, and can be categorized in several ways. For example, assets could be viewed as the sum of loans, securities and cash. However, to split them into claims on the domestic private and public sectors, and the overseas sector, is more interesting, as private borrowers and the government have different motives when they seek bank finance. It is of course the deposit liabilities which are monetary in nature and so are of most significance to the subject in hand. Non-monetary liabilities include banks' equity capital plus their bond issues plus an assortment of odds and ends, such as deferred tax. Clearly, an identity can be stated:

Change in the quantity of money (i.e., in bank deposits, and notes and coin in circulation) = Change in banking system assets - Change in its nonmonetary liabilities;

and in more detail

Change in the quantity of money $=$ Change in banks' net claims on the public sector + Change in net claims on the private sector + Change in banks' net claims on the overseas sector - Change in their non-monetary liabilities.

Central banks and the International Monetary Fund have large databases on the credit counterparts to money growth, and the information is regarded as basic to monetary analysis. ${ }^{32}$

The other approach to money creation takes its cue from banks' need to maintain cash reserves to honour obligations to customers (that is, obligations to repay deposits and to fulfil payment instructions). As has been noted, in some historical periods banks have maintained stable ratios of 
cash to deposit liabilities. In their transactions members of the non-bank public can use either cash or bank deposits, depending on their relative convenience and cost. If transactions technology is fairly stable, the ratio of the non-bank public's cash to its deposits ought also to change little over time. It follows that deposits held by the non-bank public can be viewed as a multiple of their cash holdings. Indeed, the quantity of money as a whole can be understood as a multiple of the total amount of cash issued by the central bank. ${ }^{33}$ The total amount of cash issued by the central bank is sometimes known as the monetary base or "high-powered money". The quantity of money is then equal to the "money multiplier" (or "base multiplier") times the monetary base.

The credit counterparts arithmetic and the base multiplier approach add value to thinking about the monetary situation, and no one can dispute that both are legitimate as accounting frameworks. However, some researchers have gone further and argued that the base multiplier has causal significance. They believe that, because of the assumedly wellattested stability of both non-banks' and banks' ratios of cash to deposits, an increase in the monetary base will lead to a proportionally similar increase in the quantity of money. The phrase "high-powered money" reflects this purported ability of a change in base money to engineer an expansion of the quantity of money that is a multiple of itself. Indeed, in the late 1950s and 1960s many influential economists were so impressed by the reliability of the past relationship between the base and the quantity of money that they advocated an arrangement known as "monetary base control". Since the monetary base is comprised almost entirely of its liabilities, the central bank was thought to be able to determine the amount of base in the economy. Further, with the ratios of cash to deposits taken to be more or less constant, deliberate management of the base ought - in their view - to enable the state to control the quantity of money.

Throughout his career Friedman believed in this approach to monetary control. ${ }^{34}$ A fair generalization is that Friedman did not persuade the majority of his profession that monetary base control was worthwhile or even practicable. ${ }^{35}$ Many opponents of the idea have pointed out that banks want to minimize their cash holdings, because cash is an unremunerative asset. Banks' practice is therefore to arrange credit lines with the central bank, so that they can borrow cash when withdrawals by customers are unduly and erratically large. In consequence, banks do not vary the size of their balance sheets in response to changes in the monetary base. Instead the size of the monetary base varies in response to changes in banks' borrowing needs. (The policy issues that arise when banks suffer severe cash runs, and have to borrow from the central bank as "lender of last resort", are not discussed in any detail now. However, when last-resort 
loans are extended, the central bank is concerned less with the size of the monetary base than with ensuring the convertibility of deposits into cash. An argument can be made that monetary base control is incompatible with the central bank's function of helping banks with their cash management, particularly when it has to act as lender of last resort in emergencies. $)^{36}$

Moreover, experience showed that in periods of financial stress the two key ratios - that is, of non-banks' and banks' cash to bank deposits were not stable. Notably, the Great Depression was one such period, with Friedman and Schwartz's Monetary History quantifying some of the anomalous numbers. The trauma of thousands of banks being forced to close in 1932 and 1933, in the worst phase of the downturn, caused the remaining banks to conduct their affairs with extreme caution. In particular, they operated with much higher ratios of cash reserves to deposit liabilities than in the 1920s. People and companies were also so chastened by losses on their bank deposits that sometimes they decided to hold more of their wealth in legal-tender notes and less in bank deposits. The statistical appendices at the back of A Monetary History reported that broad money fell by nearly 40 per cent between October 1929 and April 1933, but in the same period the monetary base increased by 10 per cent. ${ }^{37} \mathrm{At}$ first glance the monetary base was weak-powered as an instrument of monetary policy in this particular episode. Even admirers of Friedman and Schwartz's scholarship objected to their account of money supply determination on the grounds that it was too schematic. ${ }^{38}$ (For a counterargument, see pp. 237-42 in David Laidler's Chapter 10. Like old soldiers, some economic controversies never die.)

\section{IV}

Although it had its points of vulnerability, the Friedman and Schwartz interpretation of the Great Depression was cogent and persuasive overall. It was so influential that it ought already to have stimulated an attempt to interpret the Great Recession in similar terms. Perhaps surprisingly, at the time of writing (September 2016), hardly any such attempt has appeared in the academic literature or indeed anywhere else. The oversight is the more remarkable, in that an initial review of the evidence - such as that in the graph above - gives support to a money-based view. But the omission of money from contemporary macroeconomic discourse has become extreme. As I point out in my first contribution to this volume, a review article in the 2012 Journal of Economic Literature of 21 books on the Great Recession contained not a single reference to any money aggregate. ${ }^{39}$ 
While the discussion in this Introduction has applauded the work done by Friedman and Schwartz over 50 years ago, it has also called attention to potential flaws in it that are still problematic. These flaws weakened the case for a monetary interpretation of the Great Depression. But also, and perhaps more fundamentally, they harmed the reception of Friedman's monetary economics, and "monetarism" at large. The fault-lines in monetarist thinking have persisted in the decades since the publication of $A$ Monetary History. In summary, monetarist economists could not (and cannot) agree on the money aggregate that was (and is) most relevant to their key propositions and of greatest potency in the determination of macroeconomic outcomes, and they could not (and cannot) formulate an account of the determination of the favoured money measure which convinced (and convinces) non-monetarists.

While the contributions to this volume may not settle every problem in quantity-theory analyses, they would not have been written if all were well with policy-making before and during the Great Recession. Let it be accepted that the collapse in money growth between 2007 and 2010 indicated a policy failure of some sort. Two questions arise. Why did money growth fall so precipitously? And what were policy-makers' attitudes towards the fall in money growth, if indeed they had any organized thinking on the subject at all? Of course, the answer to the second question is crucial to understanding the attitudes and beliefs - indeed, the economic theories - that motivated policy decisions.

Readers must look at the individual chapters, as the authors here have their own views. Even so a reasonable generalization is that most contributors believe that analysis of the credit counterparts, not the monetary base, is the best way to explain the fall in money growth. (In his Chapter 10 Laidler is an exception. See p. 233 and pp. 237-41 below). In my two chapters (Chapters 1 and 2), and also in Thomas's (Chapter 3) and Hanke's (Chapter 7), the behaviour of bank lending to the private sector is seen as vital in explaining the money slowdown. Hanke, Ridley (Chapter 5) and I proceed to attack the abrupt tightening of bank regulation - particularly the demands for extra bank capital and the raising of capital/asset ratios from October 2008 - as badly mistimed and inappropriate, and as the principal influence on the crash in lending. This line is disputed by Goodhart (Chapter 6) and Thomas. They accept that the virtual cessation of new bank lending to the private sector was responsible, in an accounting sense, for the money slowdown. But they believe that in late 2008 the banking system was in danger of implosion because of the perceived insufficiency of capital in the banking system and the undoubted illiquidity of a high proportion of banks' assets. On that basis, extra bank capital was needed.

The motivation for the official emphasis on bank capital in late 2008, 
and the persistence of this emphasis in the following years, become allimportant in analysis of the Great Recession. In Chapter 2 I suggest that the G20 meetings at that time, which determined much of the policy response, were "piloted" by Ben Bernanke and Mervyn King. No doubt many other individuals were involved, but it seems that these were the two principal players. (High-level international meetings are conducted in English, and the American and British representatives set the tone. They do so, even though the UK is not now a particularly important country in terms of economic weight.) Bernanke and King are directly criticized in this volume by Hanke and myself, although not by other contributors. It is very much my view that - if the theme of policy action in autumn 2008 had been to boost the quantity of money and not to impose capital demands on the banks - the Great Recession would not have happened..$^{40}$ (Why were European voices not more vociferous in protesting against the assault on the banks? In Chapter 4 on the evolution of the European Central Bank's organization of monetary policy from 1999, Juan Castañeda and I show that the ECB's interest in a monetary "pillar" of analysis had been downgraded from 2003 onwards.)

The radical shift in UK policy in early 2009 , towards deliberate measures to boost the quantity of money in so-called "quantitative easing", and subsequent changes in the same direction in other countries, prevented further slides in demand, output and employment. (As Skidelsky remarks in Chapter 9, Keynes was an advocate of what he termed "monetary policy à outrance" to combat slump conditions. An interesting question is, "do QE and monetary policy à outrance come to much the same thing?" See note 7 on pp. 71-2 for one reply.) But the tardiness and equivocation in the move towards a quantity-of-money answer reflected muddles in academic and official thinking. As I have discussed elsewhere, leading figures in central banks, finance ministries and regulatory agencies were bemused by inconsistent and sometimes incoherent advice from economists who lacked a serviceable, well-integrated theory of the determination of national income and wealth. Any observer could see that banks and bankers were in the thick of the traumatic events in late 2008 that foreshadowed the Great Recession. But three of the four main bodies of fashionable theoretical reasoning - Old Keynesianism (income-expenditure modelling, plus an enthusiasm for fiscal policy), New Keynesianism (focused on a mere three equations, and the determination of inflation in product and labour markets with no reference to the quantity of money) and the New Classical School (concerned with expectations formation, while dismissing the banking industry as irrelevant to the business cycle) - had no room for banking and money at all. ${ }^{41}$ (Booth's analysis of asset price formation in Chapter 8 reviews New Keynesianism and the New Classical School, and compares them with quantity-theory thinking.) 
The fourth fashionable body of theory - "creditism", pioneered by Bernanke in academic articles - did pay attention to the banking industry, but in my view it looked at the wrong side of the balance sheet. According to the creditists, aggregate spending depends on bank lending by itself..$^{42}$ In the hurly-burly of the crisis period Bernanke, King and many others hurried to a superficially plausible conclusion. This was that another Great Recession/Depression could be stopped if banks had so much spare capital that they could continue lending even after suffering big losses. Here was an important element in the rationale for the late 2008 upheaval in bank regulation and the exaltation of high bank capital/asset ratios in subsequent official policy. Was that the best approach? Surely it needs to be reviewed and questioned. As banking is a risky business, it needs stable regulation. Large, arbitrary and unforeseen changes in capital/asset ratios can do - and in this case have done - immense damage. The equilibrium levels of national income and wealth are to be viewed as functions of the quantity of money, on the broad definitions, not of bank lending by itself..$^{43}$ Further, the creation of money by the state is a straightforward matter. Crucially, no extra bank capital at all is needed, as in normal jurisdictions claims on the state are free from default risk.

Sir Charles Bean, chief economist at the Bank of England from 2000 to 2008 , once remarked that the Great Recession had so many guilty parties that it was like Agatha Christie's Murder on the Orient Express. ${ }^{44}$ This is fair enough, in that many people - including the senior executives of international banking groups - did silly things in the run-up to the crisis. For example, the board of Lehman Brothers took on unhedged equity risk (with heavy investment in real estate) in a business with banking-style leverage..$^{45}$ But - as I note in Chapter 1 - the blunders of one management and the insolvency of one business (even quite a big business) should not cause an economy-wide slump in activity. Economic policy in liberal capitalist economies needs to be structured so that extensive insolvencies in a particular area of the economy, including the banking industry, can occur without causing a general downturn. The key prescription here - as Milton Friedman and many others have explained since the start of modern industrialism in the late eighteenth century - is to maintain stability in the rate of growth of the quantity of money. Ignorance about the quantity theory of money was widespread in the years leading up the Great Recession, despite Friedman's restatement over 50 years earlier. ${ }^{46}$ This volume is intended to restore interest in quantity-theory principles and analysis, so that such disasters as the 1929-33 Great Depression in the USA and the 2008-09 global Great Recession are not repeated. Perhaps it is time for another restatement of the quantity theory of money. 
The chapters in this volume reflect writings at different dates for different purposes, although they share common themes. They were not prepared for an academic conference and the book is not a collection of conference papers. Nevertheless, the themes of the following chapters were discussed at a meeting organized by the Institute of Economic Affairs and International Monetary Research Ltd in November 2013, and held at the IEA's office in London. I organized the meeting, with help from the IEA's staff, in particular Philip Booth, Christiana Hambro and Diego Zuluaga, to whom I wish to express many thanks. The chapters were not all complete when the meeting was held, and I have felt free to publish material finished many months after November 2013, and to revise contents with new facts, statistics and publications. The text of this volume was submitted to the publisher in September 2016.

I am grateful to the other participants in the IEA/International Monetary Research Ltd meeting and, above all, to those who wrote the essays that form chapters in the current volume. Each chapter stands on its own. It was no one's intention - it was certainly not mine - to impose a collegial view, even if that were possible. Perhaps all the contributors to the book agree that a monetary interpretation of the Great Recession is worth examining. But I don't want to suggest that they favour a monetary interpretation above others or that only one version of the monetary interpretation is valid.

I want to mention two further matters. First, I dislike using the first person ("in my view", "in our judgement", and so on), as it is all too often a sign that someone is losing the argument. Logic and the facts should carry the day. But I use the first person in this Introduction and the introductions to each part, simply because the result would otherwise be very stilted. In my chapters I revert to "the author". My apologies if the result seems inconsistent. Secondly, both Keynes and Friedman are abiding presences in most chapters, and references to Keynes's Collected Writings are scattered throughout the notes. Rather than write out the full title of every volume, with publisher and editorial details, I generally follow the convention of specifying the volume number next to $C W$. The only exception is the first time a reference is made to the $C W$ in each chapter's notes, when I have ensured that a full reference is given. Again, my apologies if the result seems inconsistent. 


\section{NOTES}

1. Ben Bernanke The Courage to Act (New York and London: W.W. Norton \& Company, 2015); Mervyn King The End of Alchemy (London: Little, Brown, 2016); and Hank Paulson On the Brink (New York: Hachette Book Group, and London: Headline Publishing Group, 2010).

2. This may seem overstated, but memories are short. According to George Orwell, writing in 1945, "Among the intelligentsia, it hardly needs saying that the dominant form of nationalism is Communism ... A Communist . . . is one who looks upon the USSR as his Fatherland and feels it his duty to justify Russian policy and advance Russian interests at all costs. Obviously such people abound in England today, and their direct and indirect influence is very great." Sonia Orwell and Ian Angus (eds) The Collected Essays, Journalism and Letters of George Orwell, vol. III (Harmondsworth: Penguin Books in association with Secker \& Warburg, 1971, paperback reprint of 1968 original), p. 414. For another somewhat later example, see C.P. Snow's The Two Cultures (Cambridge: Cambridge University Press, 9th printing of book with part II added, 2006, original publication 1959, based on the Rede Lecture). According to Snow, "Among the rich are the US, the white Commonwealth countries, Great Britain, most of Europe, and the USSR" (p. 41). Further, "Russia is catching up with the US in major industry ..." (p. 44).

3. Werner Keller Are the Russians Ten Feet Tall? (London: Thames and Hudson, 1961).

4. In October 1929 the US quantity of money - understood as the sum of currency held by the public, and demand and time deposits at commercial banks - was $\$ 48155 \mathrm{~m}$. In April 1933 it was $\$ 29747$ m, over 38 per cent lower. See Milton Friedman and Anna Schwartz A Monetary History of the United States, 1867-1960 (Princeton: Princeton University Press, 1963), pp. 712-14. See also p. 238 in Chapter 10 below.

5. The quotation is from p. 169 of Milton Friedman Capitalism and Freedom (Chicago: University of Chicago, 1962).

6. The quote appeared in Paul Krugman's essay 'Who was Milton Friedman?' in the 15 February 2007 issue of The New York Review of Books.

7. George Nash The Conservative Intellectual Movement in America since 1945 (New York: Basic Books, 1976), p. 287.

8. In 1970 the Institute of Economic Affairs published a pamphlet by Friedman on The Counter-Revolution in Monetary Theory (London: IEA, 1970, IEA Occasional Paper no. 33). Harry Johnson wrote a paper on 'The Keynesian Revolution and the Monetarist Counter-Revolution', which appeared the following year in the American Economic Review. (See American Economic Review, vol. 61, no. 2, Papers and Proceedings of the Eighty-Third Annual Meeting of the American Economic Association [May, 1971], pp. 1-14.) The word "monetarism" had been coined by Karl Brunner in a 1968 article ('The role of money and monetary policy') in the July 1968 issue of the Federal Reserve Bank of St Louis' Review.

9. See below, p. 252 .

10. Bernanke The Courage to Act, p. 30 .

11. Lauchlin Currie The Supply and Control of Money in the United States (Cambridge, USA: Harvard University Press, 1934), originally a doctoral thesis at Harvard, may have been the first book-length analysis of monetary data. Currie used data prepared by the US Treasury and Federal Reserve, as did Friedman and Schwartz later. I am grateful to David Laidler and Roger Sandilands for bringing my attention to Currie, who in many ways anticipated the Friedman and Schwartz work.

12. The graph, which is of monthly data, shows the six-month annualized rate of change in a broadly defined measure of money. In other words, the value for June 2009 is the actual increase in money in the six months from December 2008 to June 2009, but scaled up on the assumption that the rate of change in this six-month period continued for a full year. It was decided to express the change in a six-month annualized rate because of the weaknesses of alternatives. The annual rate misleads as it includes the experience 
of nine to twelve months earlier, while the three-month annualized rate can be erratic. The aggregate chosen was M3 in the USA, that is, the measure for which data were prepared by the Federal Reserve from 1959 to February 2006, but for which estimates by the private research company, Shadow Government Statistics, are needed subsequently. In the Eurozone the aggregate was M3, as prepared by the European Central Bank. In the UK the aggregate was M4x and the data are from the Bank of England. The M4x series was prepared by the Bank on a quarterly basis before 2009. To make the UK data monthly before 2009, interpolation has been used. The justification for adopting M4x is that the more traditional measure, M4, includes money held by so-called "intermediate other financial corporations", which are similar to banks. Like inter-bank deposits, such money balances have no obvious bearing on macroeconomic outcomes and so can properly be excluded from a money concept.

13. Mark Blaug, in a discussion published in 1985 that was sympathetic towards monetarism and the quantity theory of money, noted in the fourth edition of his much-admired Economic Theory in Retrospect that monetarism was being split into a "left wing" (emphasizing lags and other difficulties in the transmission mechanism) and a "right wing" (focusing on the purity of the comparative-static results). See Blaug Economic Theory in Retrospect (Cambridge: Cambridge University Press, 1985), p. 692.

14. Milton Friedman (ed.) The Optimum Quantity of Money (London and Basingstoke: Macmillan, 1969), p. 52.

15. Paul Samuelson The Collected Scientific Papers of Paul Samuelson (Cambridge, MA: MIT Press, 1972), vol. 3, p. 755.

16. Ben Bernanke and Mark Gertler 'Inside the black box: the credit channel of monetary policy transmission', Journal of Economic Perspectives (Nashville, TN: American Economic Association), Fall 1995 issue, vol. 9, no. 4, pp. 27-48.

17. Elizabeth Johnson and Donald Moggridge (eds) The Collected Writings of John Maynard Keynes, vol. VII: The General Theory of Employment, Interest and Money (London and Basingstoke: Macmillan for the Royal Economic Society, 1973), pp. 84-5.

18. The paper was republished as Milton Friedman and Anna Schwartz 'Money and business cycles', in Milton Friedman (ed.) The Optimum Quantity of Money, pp. 189-235.

19. Friedman (ed.) The Optimum Quantity of Money, pp. 229-34.

20. Friedman (ed.) The Optimum Quantity of Money, footnote 2 at the bottom of p. 172.

21. Inter-bank deposits are excluded from money, which creates a problem for the deposits of organizations which are quasi-banks. Hence the word "genuine", to define the relevant non-banks, is used in the text. Definitional issues also arise with deposits held by non-residents and with foreign currency deposits held by residents.

22. The Federal Reserve stopped preparing M3 data in February 2006. The M3 figure given in the text is taken from data prepared by the research company, Shadow Government Statistics, which guesstimates the M3 total from publicly available information about M3's components. For further discussion, see Tim Congdon Money in a Free Society (New York: Encounter Books, 2011), pp. 346-50.

23. Allan Meltzer A History of the Federal Reserve, vol. 1, 1913-51 (Chicago, USA and London, UK: University of Chicago Press, 2003), p. 372.

24. Robert Lucas Collected Papers on Monetary Theory (Cambridge, MA and London, UK: Harvard University Press, 2013), 'Review of Milton Friedman and Anna Schwartz A Monetary History of the United States, 1867-1960', pp.361-74. The paper originally appeared in the first issue of the 1994 Journal of Monetary Economics. For more on the New Classical School, see p. 196 in Philip Booth's Chapter 8 below.

25. The evolution of monetary data preparation in the USA is surprisingly complex. See Richard Anderson and Kenneth Kavajecz 'A historical perspective on the Federal Reserve's monetary aggregates: definition, construction and targeting', Federal Reserve Bank of St. Louis Review, vol. 76, no. 2, March/April 1994, pp. 1-31.

26. Edward Nelson 'Milton Friedman and US monetary history: 1961-2006', Federal Reserve Bank of St Louis Review, vol. 89, no. 3, 2007, pp. 153-82. See, particularly, p. 163. 
27. Samuelson's 1948 textbook - by far the best-selling economics textbook of all time included a section on Hicks' IS-LM model, originally proposed in Hicks' 1937 review article on The General Theory. The LM function represented those points where both the interest rate and national income were consistent with the equivalence of money demand with money supply. So Samuelson's textbook did include money. But Samuelson and the Keynesians differed from the monetarists over a wide front. Quite apart from the matters discussed in the main text here, the Keynesians and the monetarists disagreed on the relative importance of money and other economic drivers in the determination of national income, and on the direction of causation. The Keynesians were inclined to regard money as being determined by the economy; they did not see macroeconomic variables as being determined by the banking system and the quantity of money.

28. Friedman (ed.) The Optimum Quantity of Money, pp. 4-5.

29. In November 2002 Bernanke gave a speech in which he mentioned "helicopter money" as a weapon to defeat entrenched deflation. He was advised by the Fed's media relations officer to drop it, as it was too recondite for financial markets to appreciate. Bernanke The Courage to Act, p. 64.

30. John Kenneth Galbraith Money: Whence it Came, Where it Went (Boston: Houghton Mifflin, 1975), p. 29.

31. See p. 58 of Gordon Pepper and Michael Oliver The Liquidity Theory of Asset Prices (Chichester: John Wiley \& Sons, 2006) for fountain-pen money; see pp. 43-7 of William Barber The Works of Irving Fisher, vol. 11: 100\% Money (London: Pickering \& Chatto, 1997, originally published 1935) for cheque-book money, or "check-book money" in Fisher's American spelling; the phrase "keyboard money" has appeared in newspapers in recent years, to express the typing of scriptural money amounts on computer keyboards.

32. Perhaps the most important of the papers crucial to the development of credit counterparts analysis was written in the mid-1950s by the International Monetary Fund's second head of research, Jacques Polak. See Jacques Polak 'Monetary analysis of income formation and payments problems', IMF Staff Papers (Washington: IMF, 1957), vol. 6, issue 1, pp. 1-50. See also Gerald Steel 'The credit counterparts of broad money: a structural base for macroeconomic policy', Lancaster University Management School Economic Working Paper Series, 2014, no. 4.

33. The derivation of the banking system multiplier is a textbook commonplace. But see, for example, Friedman and Schwartz A Monetary History of the United States, pp. 776-808 for a rigorous treatment and pp. 238-9 in David Laidler's Chapter 10 below.

34. Friedman A Program for Monetary Stability (New York: Fordham University Press, 1959, based on the Millar Lectures) was Friedman's earliest extended discussion of the topic.

35. For an example of a measured critique of monetary base control, see Chapter VII (pp. 202-18) in Charles Goodhart Monetary Theory and Practice (London: Macmillan, 1984).

36. I made this argument in Tim Congdon 'First principles of central banking', The Banker, April 1981 issue. It is also one theme of Tim Congdon Central Banking in a Free Society (London: Institute of Economic Affairs, 2009).

37. See note 4 above and Friedman and Schwartz A Monetary History of the United States, 1867-1960, pp. 803-4.

38. James Tobin 'A monetary interpretation of history', Chapter 23, in Essays in Economics: vol. 1 Macroeconomics (Amsterdam: North Holland, 1971), pp.471-96. See, especially, pp.476-81. The chapter originally appeared as a review article in the 1965 American Economic Review.

39. See p. 48 below.

40. I accept that a cyclical reverse after the excessive money growth of 2005-07 was unavoidable, but in my view it ought to have been mild. In early 2007 I warned of trouble ahead in evidence to the House of Commons' Treasury Committee, but I had 
no inkling of the severity of the setback that was to happen. I did not anticipate - and could not have anticipated - the folly of international officialdom (as I see the matter) in late 2008. Drastic changes in bank regulation of the kind seen in late 2008 had never occurred before.

41. Tim Congdon Money in a Free Society (New York: Encounter Books, 2011), pp. xii-xix.

42. See note 20 to Chapter 2 on p. 74 for more discussion of creditism.

43. Of course new bank lending to the private sector creates new money balances, and money matters in the usually understood fashion. National income is a function of the quantity of money, not of the loans that banks extend.

44. Every passenger in the train compartment was involved in the murder of a villain.

45. Lawrence McDonald and Patrick Robinson A Colossal Failure of Common Sense: The Inside Story of the Collapse of Lehman Brothers (New York: Three Rivers Press, 2009).

46. Friedman The Optimum Quantity of Money, pp. 51-68, reprinted from Milton Friedman (ed.) Studies in the Quantity Theory of Money (Chicago: University of Chicago Press, 1956). 